INTERNATIONAL MONETARY FUND

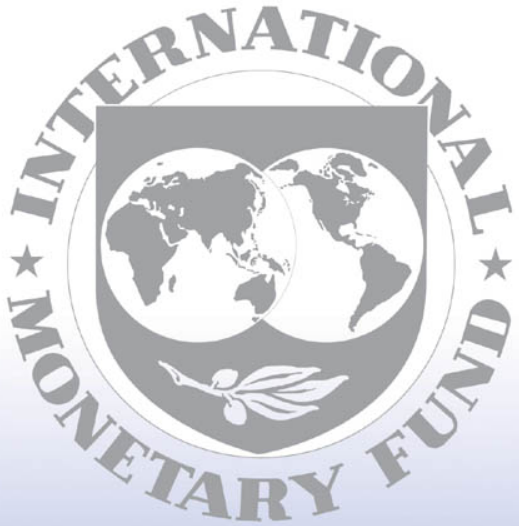

Staff

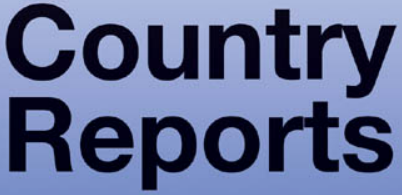




\section{The Federal Democratic Republic of Ethiopia: Ex Post Assessment of Long-Term Fund Engagement}

This Ex Post Assessment of Long-Term Fund Engagement paper for The Federal Democratic Republic of Ethiopia was prepared by a staff team of the International Monetary Fund as background documentation for the periodic consultation with the member country. It is based on the information available at the time it was completed on August 18, 2004. The views expressed in this document are those of the staff team and do not necessarily reflect the views of the government of The Federal Democratic Republic of Ethiopia or the Executive Board of the IMF.

The policy of publication of staff reports and other documents by the IMF allows for the deletion of market-sensitive information.

To assist the IMF in evaluating the publication policy, reader comments are invited and may be sent by e-mail to publicationpolicy@imf.org.

Copies of this report are available to the public from

International Monetary Fund $\bullet$ Publication Services

700 19th Street, N.W. • Washington, D.C. 20431

Telephone: (202) 6237430 • Telefax: (202) 6237201

E-mail: publications@imf.org • Internet: http://www.imf.org

Price: $\$ 15.00$ a copy

International Monetary Fund

Washington, D.C. 
This page intentionally left blank

CInternational Monetary Fund. Not for Redistribution 


\section{INTERNATIONAL MONETARY FUND}

\section{THE FEDERAL DEMOCRATIC REPUBLIC OF ETHIOPIA}

\section{Ex Post Assessment of Long-Term Fund Engagement}

Prepared by a staff team from African, Fiscal Affairs, Monetary and Financial Systems, and Policy Development and Review Departments ${ }^{1}$

Authorized for circulation by Siddharth Tiwari and Matthew Fisher

August 18, 2004

Contents

I. Introduction .$\underline{3}$

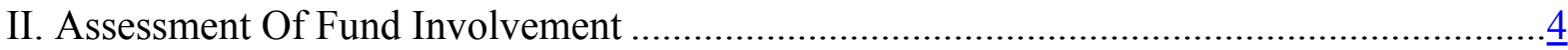

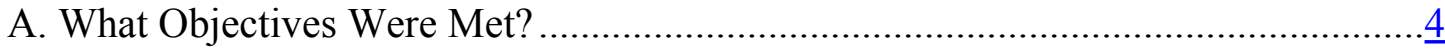

B. What Objectives Were Not Met? .................................................................

C. Compliance with Program Conditionality......................................................16

D. Were the Objectives and the Program Design Appropriate? .................................19

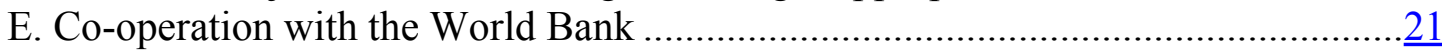

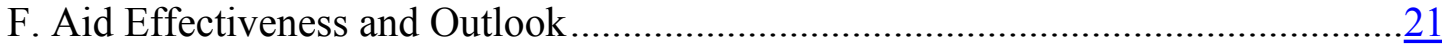

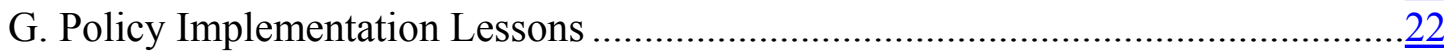

III. Medium-Term Development Goals and Strategy for Future Fund Involvement ...............24

A. Medium-Term Development Goals ...............................................................

B. Strategy for Future Fund Involvement ...............................................................

Tables

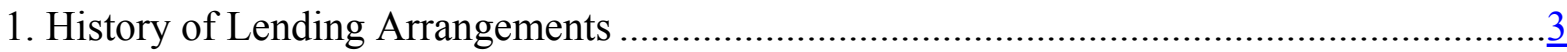

2. Selected Social and Demographic Indicators ..................................................................

3. Performance Under the SAF, the ESAF, and the PRGF Arrangements ................................

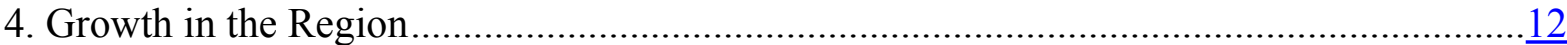

5. Compliance with Quantitative Program Targets Under the SAF, the ESAF, and PRGF

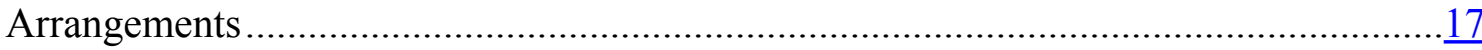

6. Program Conditions Versus Other Similar Arrangements................................................

\footnotetext{
${ }^{1}$ The team comprised J. Daniel (Head, FAD), L. Erasmus, R. Powell, A. Yamauchi (all AFR), M. Horton, W. Maliszewski (both FAD), J. Vadasz (MFD) and H. Tadesse (PDR).
} 


\section{Figures}

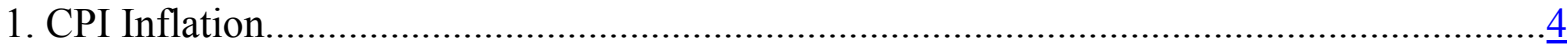

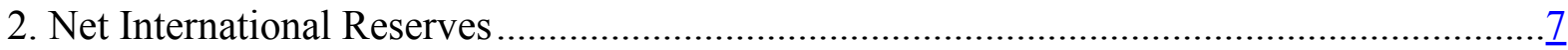

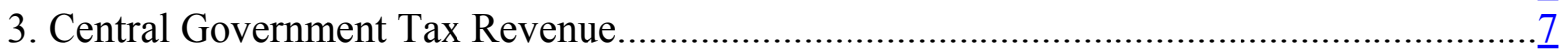

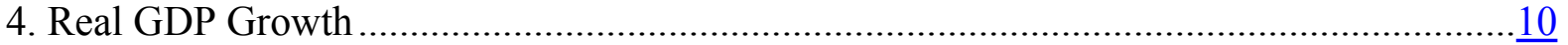

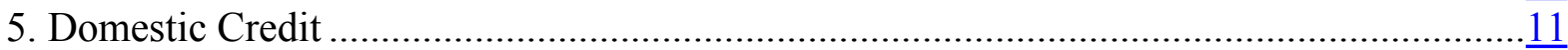

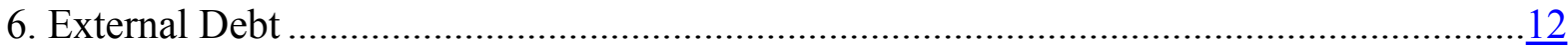

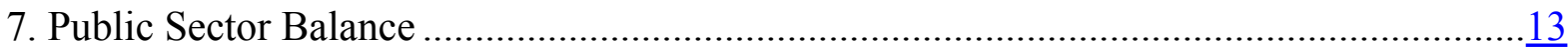

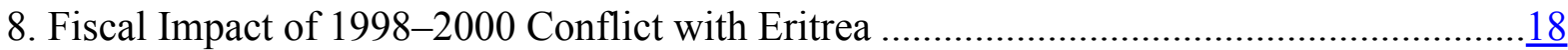

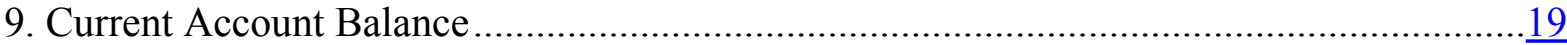

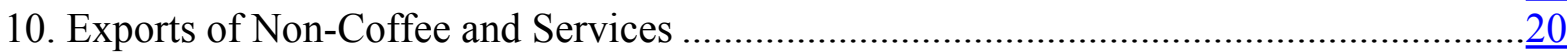

11. Governance Indicators Compared to those of Sub-Saharan Africa ...................................22

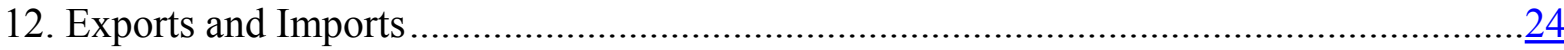

\section{Boxes}

1. The Impact of Rainfall on Real GDP.

2. Ethiopia and Tanzania-A Comparison

Appendix Tables

1. Performance Against Structural Program Conditions. 


\section{INTRODUCTION}

\section{From 1974 to 1991 Ethiopia was ruled as a socialist state under a military} dictatorship, the Provisional Military Administrative Council, also known as the Derg. When it assumed office in 1991, the Ethiopia Peoples' Revolutionary Democratic Front inherited an economy crippled by years of civil war and misguided policies. Economic performance under the Derg was hindered by excessive central planning, suppression of market forces, environmental degradation, recurrent drought, falling terms of trade, unsettled domestic security, and - particularly in the late 1980s — weakening financial discipline.

\section{Cautious fiscal and incomes policies, as well as pervasive price controls, kept} inflation at moderate levels through the mid-1980s. Budgetary pressures were contained through high levels of taxation. However, the peak revenue performance (over 30 percent of GDP) could not be maintained and domestic bank financing of the budget rose sharply towards the end of the civil war in 1991.

\section{The external current account was contained by exchange and trade restrictions} under the Derg regime. Exports stagnated, reflecting an overvalued exchange rate, and debt service obligations rose. The Soviet Union provided Ethiopia with substantial loans for both economic development and defense. With the collapse in world coffee prices in 1989/90, and falling official aid, Ethiopia began to accumulate external payments arrears and foreign exchange reserves fell. A SAF was approved in $1992^{2}$, soon after the establishment of a new government, followed by an ESAF in 1996 and a PRGF in 2001 (Table 1).

Table 1. Ethiopia: History of Lending Arrangements Since 1990

(In thousands of SDRs)

\begin{tabular}{|c|c|c|c|c|c|c|}
\hline Facility & $\begin{array}{c}\text { Date of } \\
\text { Arrangement } \\
\end{array}$ & $\begin{array}{c}\text { Date of Expiration } \\
\text { or Cancellation }\end{array}$ & $\begin{array}{c}\text { Amount } \\
\text { Agreed }\end{array}$ & $\begin{array}{l}\text { Amount } \\
\text { Drawn }\end{array}$ & $\begin{array}{l}\text { Percent } \\
\text { Drawn } \\
\end{array}$ & Note \\
\hline SAF & $10 / 28 / 92$ & $11 / 08 / 95$ & 49,420 & 49,420 & 100.0 & All reviews were completed, and disbursements made. \\
\hline ESAF & $10 / 11 / 96$ & $10 / 31 / 99$ & 88,470 & 29.490 & 33.3 & $\begin{array}{l}\text { Only two of the six disbursements were made. The first drawing } \\
\text { was made upon Board approval of the first annual arrangement } \\
\text { (October 1996), but no further drawings were made as the mid- } \\
\text { term review could not be completed-and the arrangement was } \\
\text { allowed to lapse on October 10, } 1997 \text {. The second drawing was } \\
\text { made upon Board approval of the second annual arrangement } \\
\text { (October 1998), but again no further drawings were made as the } \\
\text { mid-term review also could not be completed. The 3-year ESAF } \\
\text { expired in October } 1999 \text {. }\end{array}$ \\
\hline PRGF & $3 / 22 / 01$ & $10 / 31 / 04$ & $\begin{array}{c}100,27 \\
7\end{array}$ & 89.848 & 89.6 & $\begin{array}{l}\text { Ongoing. The arrangement was augmented by SDR } 13.377 \text { million } \\
\text { on the occasion of the second review to mitigate the impact on the } \\
\text { balance of payments of the continued deterioration in the terms of } \\
\text { trade, and the events of September } 11,2001 \text {. So far all scheduled } \\
\text { reviews have been completed, of trade, and the events of } \\
\text { September } 11,2001 \text {. So far all scheduled reviews have been } \\
\text { completed, and disbursements made. Completion of the fourth } \\
\text { review was however delayed by six months on account of a delay } \\
\text { in the completion of a financial audit of the Commercial Bank of } \\
\text { Ethiopia (structural benchmark). The arrangement was therefore, } \\
\text { extended by four months. }\end{array}$ \\
\hline
\end{tabular}

Source: IMF, FIN Department.

\footnotetext{
${ }^{2}$ This was Ethiopia's second arrangement; the first was a SBA in 1981-82.
} 


\section{ASSESSMENT OF Fund INVOLVEMENT}

\section{Fund involvement since 1992 helped underpin the authorities' gradualist}

policies. Because ownership was strong, compliance has been generally good. But ownership is only a necessary, not sufficient, condition for success and Ethiopia's pressing needs called for a more ambitious reform strategy. And therein lies the dilemma: a more ambitious agenda may well not have been supported or accepted by the authorities, which in turn would have resulted in either failed, or no, Fund-supported programs.

\section{Fund-supported programs (the SAF) initially aimed at stabilizing the economy} and breaking with the legacy of central planning. Later programs (the ESAF and PRGF) emphasized structural reform to support sustainable high growth and poverty reduction. While macroeconomic stability has been largely achieved, structural reform was gradual and piecemeal, especially under the ESAF. Many of the most immediate and distortionary policies of the centrally-planned past have been overhauled, but the authorities have remained cautious of greater market orientation in key areas, such as land, enterprise ownership, agriculture and the financial sector, and progress on "second-generation" reforms has been modest, though improving under the PRGF. And while most social indicators have improved over the program periods, they generally remain worse than those of other SubSaharan African (SSA) and Low-Income Countries (Table 2).

\section{A. What Objectives Were Met?}

\section{Macroeconomic objectives}

6. Inflation was brought down rapidly, and has generally been lower than targeted, though volatile, and has recently spiked due to the drought (Table 3 and Figure 1). On average, programs targeted annual consumer inflation rates of about 7 percent; while the actual was about 3 percent. The volatility generally reflected agricultural conditions and exogenous shocks.

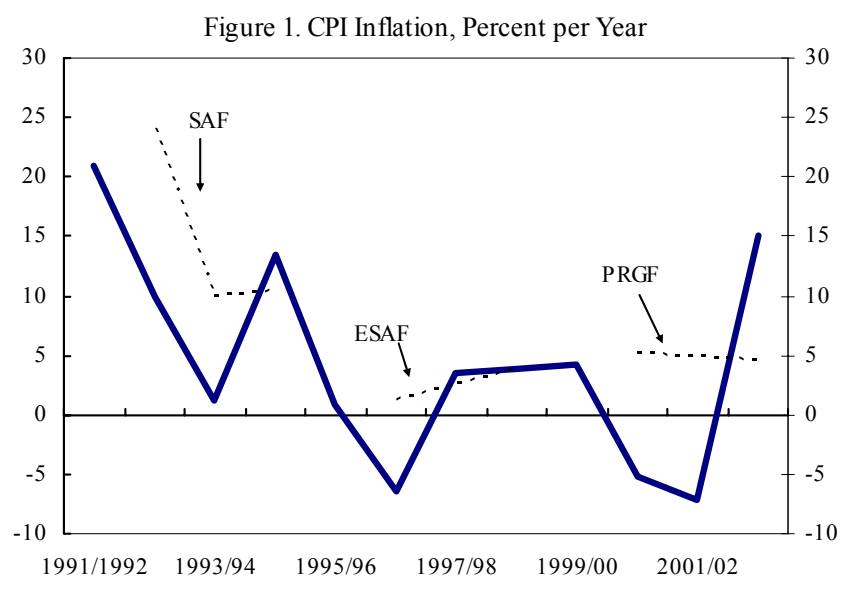


Table 2. Ethiopia: Selected Social and Demographic Indicators

\begin{tabular}{|c|c|c|c|c|c|c|c|c|c|c|}
\hline & \multicolumn{3}{|c|}{ Ethiopia } & & \multicolumn{2}{|c|}{ Sub-Saharan Africa } & & \multicolumn{3}{|c|}{ Low-income countries } \\
\hline & 1992 & & 2001 & & 1992 & 2001 & & 1992 & 2001 & \\
\hline \multicolumn{11}{|l|}{ I. Population characteristics } \\
\hline \multicolumn{11}{|l|}{ Life expectancy at birth (years) } \\
\hline Total & 45.3 & & 42.2 & & 50.0 & 46.2 & & 57.7 & 58.9 & \\
\hline Female & 46.7 & & 43.1 & & 51.6 & 47.0 & & 58.7 & 60.0 & \\
\hline Male & 43.9 & & 41.3 & & 48.6 & 45.4 & & 56.8 & 57.9 & \\
\hline Mortality rate, infant (per 1,000 live births) & 193.0 & $1 /$ & 172.0 & & $178.21 /$ & 170.6 & & $139.31 /$ & 120.6 & \\
\hline Birth rate, crude (per 1,000 people) & 49.0 & & 43.1 & & 43.3 & 39.1 & & 32.8 & 28.7 & \\
\hline Death rate, crude (per 1,000 people) & 20.2 & & 20.1 & & 15.4 & 17.2 & & 11.5 & 10.9 & \\
\hline Fertility rate, total (births per woman) & 6.8 & & 5.6 & & 5.9 & 5.1 & & 4.2 & 3.5 & \\
\hline \multicolumn{11}{|l|}{ II. Education } \\
\hline \multicolumn{11}{|l|}{ Illiteracy rate (in percent) } \\
\hline Adult total (of population $15+$ ) & 69.4 & & 59.7 & & 48.0 & 37.7 & & 43.8 & 37.0 & \\
\hline Young adult female (aged 15-24 years) & 63.1 & & 49.8 & & 37.5 & 26.6 & & 38.2 & 30.4 & \\
\hline Young adult male (aged $15-24$ years) & 46.5 & & 37.9 & & 23.4 & 17.4 & & 23.0 & 18.4 & \\
\hline \multicolumn{11}{|l|}{ School enrollment (in percent) } \\
\hline Primary, gross enrollment & 22.9 & & 64.4 & $3 /$ & 73.0 & 86.3 & $3 /$ & 90.0 & 94.6 & $5 /$ \\
\hline Female & 18.8 & & 52.4 & 3/ & 66.7 & 80.2 & $3 /$ & 80.9 & 87.5 & $5 /$ \\
\hline Male & 27.0 & & 76.4 & 3/ & 79.5 & 92.4 & $3 /$ & 98.9 & 103.0 & $5 /$ \\
\hline Secondary, gross enrollment & 11.2 & & 18.0 & 3/ & 23.8 & 26.6 & 4/ & 38.6 & 44.5 & $5 /$ \\
\hline Female & 10.6 & & 14.3 & 3/ & 21.2 & 23.9 & 4/ & 31.6 & 39.1 & $5 /$ \\
\hline Male & 11.8 & & 21.7 & $3 /$ & 26.6 & 29.2 & 4/ & 45.3 & 49.6 & $5 /$ \\
\hline Primary, net enrollment & 20.4 & 2/ & 46.7 & $3 /$ & n.a. & n.a. & & n.a. & n.a. & \\
\hline Pupil-teacher ratio, primary education & 26.6 & & 54.9 & $3 /$ & 38.9 & 46.7 & $3 /$ & 32.1 & 38.9 & $5 /$ \\
\hline \multicolumn{11}{|l|}{ III. Health } \\
\hline \multicolumn{11}{|c|}{ Immunization (in percent of children under 12 months) } \\
\hline DPT & 13.0 & & 56.0 & & 49.2 & 52.9 & & 55.7 & 61.5 & \\
\hline Measles & 12.0 & & 52.0 & & 50.3 & 57.8 & & 54.4 & 59.8 & \\
\hline Access to safe water (in percent of population) & 25.0 & $1 /$ & 24.0 & $3 /$ & $53.21 /$ & 58.1 & $3 /$ & $66.41 /$ & 76.1 & $3 /$ \\
\hline \multicolumn{11}{|l|}{ IV. Land use } \\
\hline Arable land (in percent of total land area) & 10.0 & $2 /$ & 10.0 & $3 /$ & 6.0 & 6.6 & $3 /$ & 12.9 & 13.1 & $3 /$ \\
\hline \multicolumn{11}{|l|}{ V. Labor force } \\
\hline Total (in percent of total population) & 44.2 & & 42.9 & & 44.1 & 44.2 & & 43.9 & 45.4 & \\
\hline Female (in percent of total) & 40.9 & & 40.9 & & 41.8 & 42.0 & & 37.1 & 37.9 & \\
\hline
\end{tabular}

Source: World Bank, World Development Indicators, 2003.

1/ Data as of 1990.

2/ Data as of 1993.

3/ Data as of 2000

4/ Data as of 1998.

5/ Data as of 1999. 
ESAF 4/ 2019

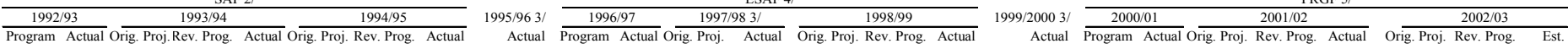

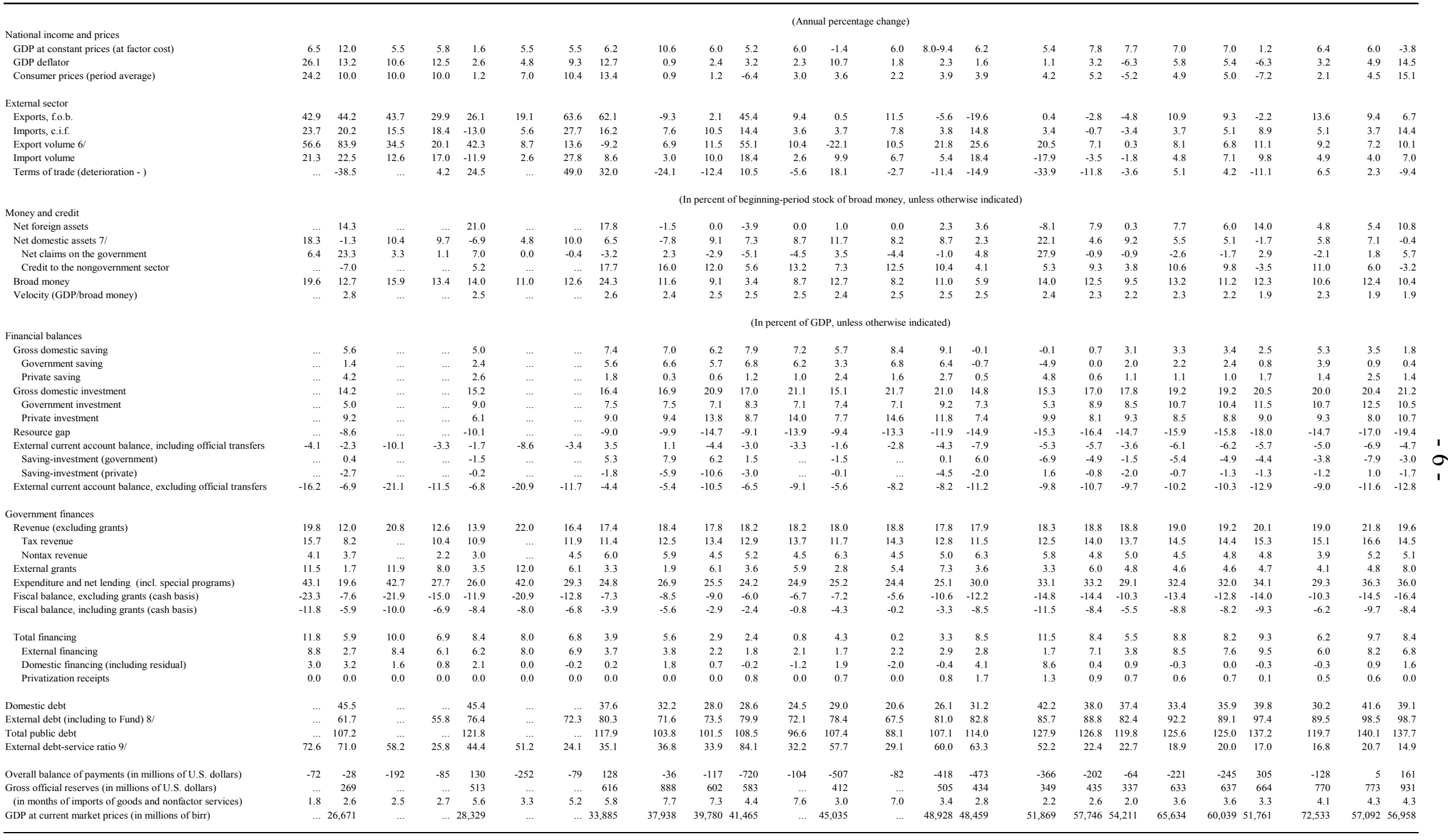

Sources: Ethiopian authonities, and fund staff estimates and projections.

1/ Data pertain to the period July 8-July 7 . "Onignal projection "refer to projections under the corresponding program at the time of the request. "Revised program" refers to projections under the program revised prior to the start of an annual program.

2/ Eash fiscal year corresponds to the annual program under the three-year SAF arrangement.

There was no Fund-supported program.

$5 /$ The first and second annual program under the three-year PRGF arrangement covered the period October-September. Following a postponement of the fourth review by six months, the third annual program was aligned in line with the fiscal year $2003 / 04$.

6/ Noncoffee exports for 1994/95-1996/97.

/ After traditional debt relief. Excluding ruble-denominated debts to Russia through 1998/99, while actual and revised program numbers under the ESAF arrangement include them. 
7. Targets on international reserves were generally met and reserves have grown significantly from low starting levels (Figure 2). Current account deficits have generally turned out better than projected, though relative to high-programmed levels. ${ }^{3}$ Debt service relief assisted the buildup of reserves by easing immediate cash-flow constraints. External borrowing has generally been in line with program assumptions.

\section{Nongrant revenue rose}

significantly after a substantial shortfall in the first year of the SAF arrangement (Figure 3). The shortfall in the first year of the SAF stemmed from delays in the use of an auction-based exchange rate for import valuation and slower than expected price liberalization. Changes in the tax structure led to revenue gains from indirect taxes, mostly on imports, while revenue from direct taxes declined.

\section{Structural reform objectives}

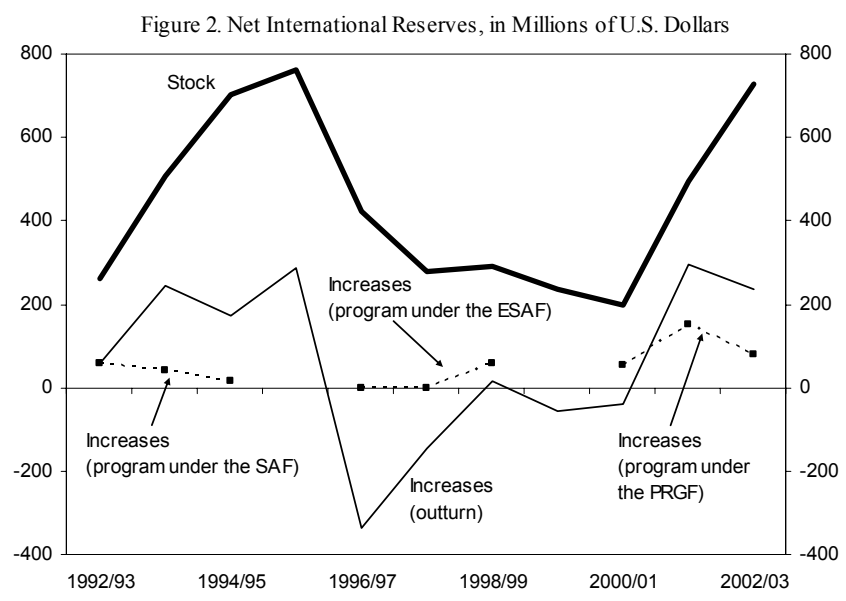

Figure 3. Central Government Tax Revenue, Percent of GDP

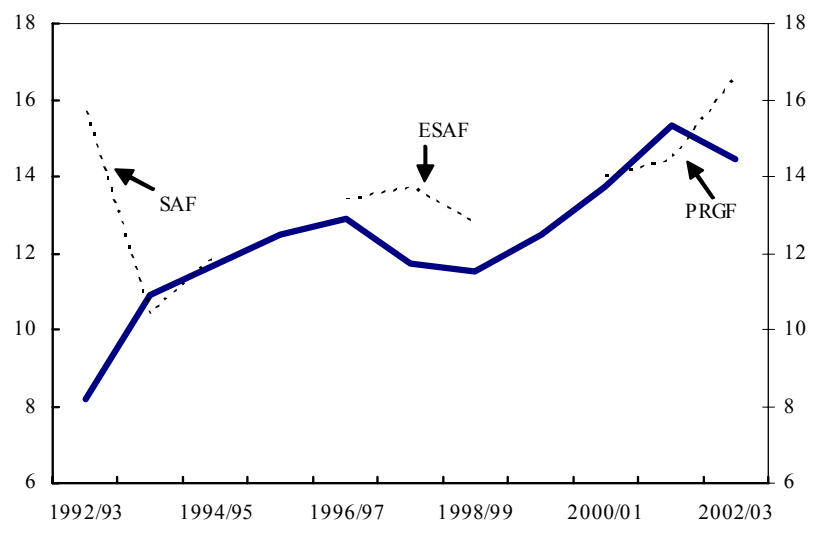

\section{External sector}

9. The trade regime was liberalized: maximum tariffs were reduced from 230 percent under the Derg to 35 percent by 2003; average tariffs were reduced from 41.6 percent in the mid-1990s to 17.5 percent; the number of tariff bands was lowered from 23 to 6; and an open import licensing system (with a negative list) was introduced, quantitative import restrictions were removed, export subsidies and import surcharges were eliminated.

10. The highly overvalued exchange rate was devalued: after considerable delay, the birr was devalued by 59 percent against the US dollar in October 1992. Gradual nominal depreciations since then have prevented a real appreciation.

\footnotetext{
${ }^{3}$ The SAF projected a sharp increase in the current account deficit to accommodate large amounts of reconstruction. Given the high starting levels for the current account deficit, the decline targeted in the ESAF (2.3 percent of GDP) was larger than the average for other ESAF programs, but that under the PRGF (1.7 percent of GDP) matches the average decline sought in other PRGF programs.
} 
11. Impediments to exports were removed: beyond the sharp devaluation in 1992, the government's monopoly in coffee trade was eliminated; export taxes were removed; automatic granting of export licenses was introduced; and a duty drawback system was implemented. Reflecting the improved policy environment, non-coffee exports have shown steady increases and coffee exports (now handled by the private sector) have more than doubled in volume (although export receipts during the same period rose by only a third due to falling prices).

12. Relations with creditors were normalized, nonconcessional external borrowing was avoided, ${ }^{4}$ and more sectors were opened to foreign investors.

Fiscal sector

13. The tax system improved, gradually at first, then more rapidly with the PRGF: the structure and coverage of the income tax was enhanced through rationalization of brackets, reduction of high marginal rates, more consistent treatment of income from different sources, extension of withholding tax to self-employed individuals, and to interest income and capital gains; the stamp duty was replaced with a tax on the value of financial services in 1997/98; the sales tax was reformed and, critically, a VAT was introduced in 2003 (though much delayed due to the 1998-2000 conflict with Eritrea and technical problems). ${ }^{5}$

14. As with tax policy, revenue administration reforms accelerated under the PRGF, with the creation of the tax reform project office, the formation of the Ministry of Revenues, the establishment of a large taxpayer unit and implementation of the VAT, and implementation of new working practices and simplification of procedures in customs. ${ }^{6}$

\section{Expenditure was reoriented towards more productive and poverty-reducing} areas, though the border conflict with Eritrea was a major setback: poverty-reducing spending under the PRGF arrangement rose from 8 percent of GDP in 1999/00 to 15 percent of GDP in 2002/03; a rolling, three-year public investment program was introduced (after repeated delays); and sector investment programs have helped improve coordination of donor support in health, education, agriculture, and transport.

\footnotetext{
${ }^{4}$ Except for nonguaranteed Ethiopian Airlines loans.

${ }^{5}$ The poverty and social impact analysis of the VAT, while welcome, should ideally have been done before, rather than after, the introduction of the VAT. The delay in the PSIA was, however, due to problems in donor financing.

${ }^{6}$ The introduction of Taxpayer Identification Numbers was, however, delayed significantly and continues to be a weak point of implementation. The ASYCUDA system has also been utilized only in a limited, statistical, manner and not to facilitate customs operations.
} 
16. Progress was made in public expenditure management: an organic budget law was adopted; medium-term expenditure planning and the budget classification and formats were strengthened; computerized budget disbursement and accounting systems were adopted; the use and accounting for donor resources was improved; cash management was strengthened; and human resource development and training was improved. More generally, the authorities' simple, disciplined, approach has prevented domestic expenditure arrears. The comprehensiveness of budget formulation and fiscal reporting has also improved recently through the incorporation of extrabudgetary funds into the consolidated general government fiscal reports, and classification of expenditure has been strengthened.

\section{Deregulation}

17. Prices were liberalized: most were liberalized during the SAF and controls on pharmaceutical products were phased out during 1996/97; only petroleum prices remain regulated and in 1996, an automatic pricing system for petroleum products was implemented.

\section{Financial sector}

18. Some progress was made towards establishing a competitive financial system, including: authorization of domestic privately-owned financial institutions; adoption of bank provisioning regulations for nonperforming loans (NPLs); an increase in the minimum capital of banks to birr 75 million from birr 10 million; comprehensive audit of the Commercial Bank of Ethiopia (CBE), reducing its NPLs (though they remain high at 54 percent of loans), and hiring of reputable international consultants; commencement of restructuring the $\mathrm{CBE}$ and introduction of measures for improving the soundness of the financial system; permission for private banks to enter into management contracts with foreign entities; and authorization for the operation of foreign exchange bureaus as subsidiaries of banks.

\section{Market forces and the National Bank of Ethiopia's (NBE) supervisory} instruments were enhanced: control over bank lending rates was lifted and sector-specific lending rates ended; the minimum deposit rate was set at a positive real level; limited types of indirect monetary policy operations were initiated; a treasury bill market was created; and a framework for the conduct of interbank money market operations and for banks to trade surplus funds in the interbank market was created.

20. A largely market-oriented foreign exchange system was established: fortnightly, then weekly, wholesale foreign exchange auctions were initiated in May 1993 and September 1998, respectively, and a daily interbank foreign exchange market was introduced in October 2001; the repatriation and conversion requirement for exporters was relaxed (exporters may now keep 10 percent of their proceeds without a time limit, and the remainder for 28 days); the advance cover requirement for participation in the auctions was eliminated; and exporters and recipients of private remittances were allowed to open foreign currency deposit accounts. 


\section{Progress was made towards liberalizing foreign exchange operations and} eliminating Article VIII restrictions: the multiple currency practice, which might have arisen from the weekly foreign exchange auction was lifted with the above-mentioned establishment of the interbank foreign exchange market; several restrictions on payments and transfers have been eliminated or relaxed; specifically, limits on external current account transactions for business and holiday travel, education, and health have been eliminated; responsibility was transferred from the NBE to the commercial banks for determining compliance of foreign exchange buyers and sellers with import and export licensing requirements and foreign exchange regulations; and foreign exchange bureaus were allowed to engage in all approved spot/cash external current account transactions.

\section{B. What Objectives Were Not Met?}

\section{Macroeconomic objectives}

\section{Growth was weaker than targeted and highly volatile (see} Table 3 and Figure 4). The programs aimed at annual real growth rates of about $6 \frac{1}{2}$ percent; actual growth rates during program periods were slightly under 4 percent. ${ }^{7}$ The main reason for the poor performance was weak agricultural growth (1 percent on average). Growth was also highly volatile, driven by agricultural

Figure 4. Ethiopia: Real GDP Growth, Percent per Year

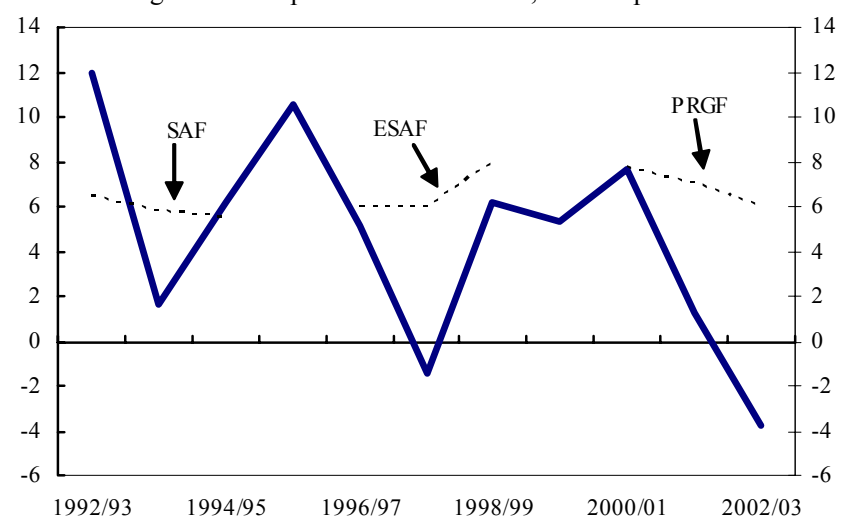
conditions, with the average absolute difference between program projections and actuals of just over 4 percentage points, reflecting the lack of progress in reducing vulnerability and food insecurity (Box 1). Nevertheless, growth since 1993 has been substantially above that of the previous decade and above that of many other countries in the region (though more volatile). GDP growth per capita has averaged 1.6 percent in 1993-2003, which is higher than the Sub-Saharan African average of 0.4 percent (Table 4 ), though slower than the faster reformers.

\footnotetext{
${ }^{7}$ Including preliminary estimates for 2003/04, this figure would rise to 4.7 percent.
} 
23. Credit to the private sector did not increase as strongly as projected, except for a couple of years in the mid1990s (Figure 5). ${ }^{8}$ Partly reflecting this, private investment also underperformed, averaging about 8 percent as a share of GDP during past decade, well below the average for Sub-Saharan Africa.
Figure 5. Ethiopia: Domestic Credit, Annual Percentage Change Relative to M2 at the Beginning of the Period

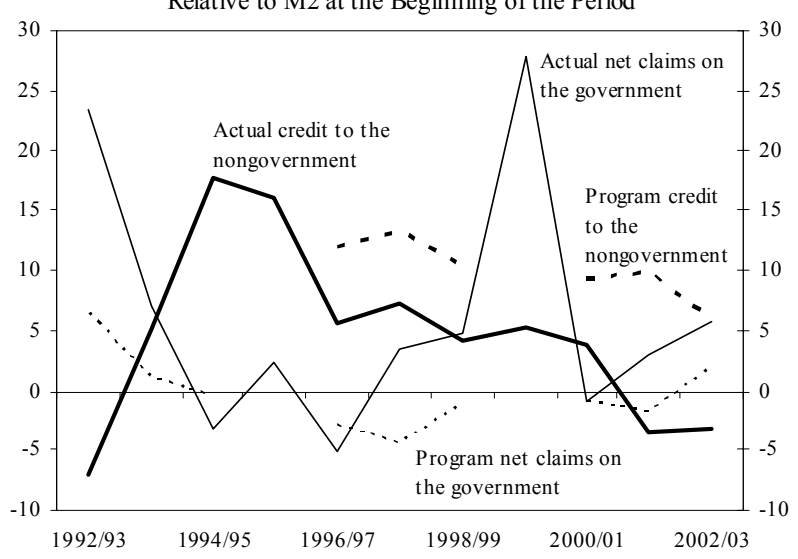

\section{Box 1. The Impact of Rainfall on Real GDP}

Growth in Ethiopia depends highly on rainfall, largely due to the importance and structure of the agricultural sector. During 1981-2002, the agricultural sector accounted for about half of GDP. Agricultural production is also almost entirely based on small-scale farming, and heavily dependent on rainfall (less than 3 percent of cultivated area is under irrigation). Shocks to agricultural production stem from two main sources, fluctuations in rainfall, and in the terms of trade (coffee exports during 1989/90-2002/03, for example, on average accounted for more than half of total exports).

Econometric analysis suggests that rainfall and a trend explain about 94 percent of the variance of real GDP. A simple regression framework is used to explore the relationship between the level of real GDP and these two factors for the period 1974-2002. (While the terms of trade had the "correct" sign, it was not statistically significant.) The average annual rainfall and trend growth were both highly significant, and had the expected signs. Fluctuations in average annual rainfall, in particular, appear to have a substantial impact on real GDP, with a change of 1 percent in rainfall leading to a change in real GDP of 0.3 percent in the next year.

The dependence of agricultural production on rainfall causes real GDP growth to be very

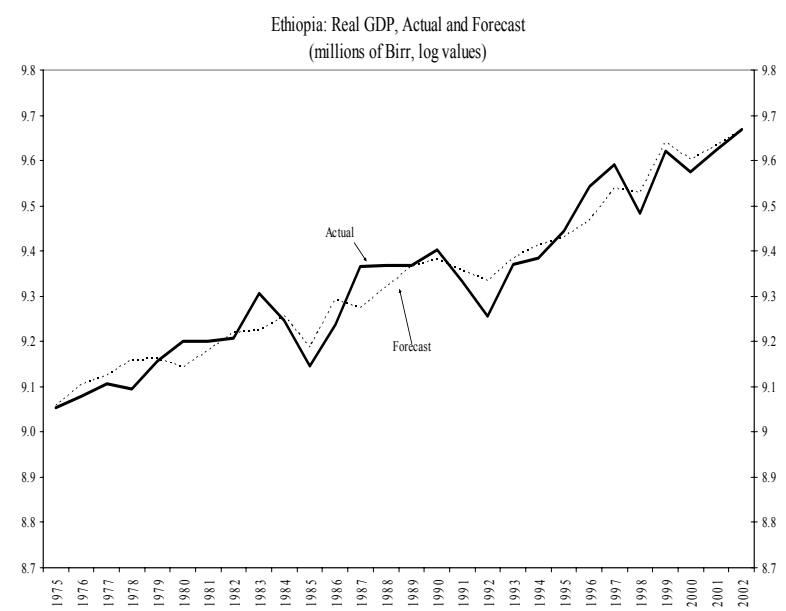
volatile. The standard deviation of growth was 6.5 relative to the mean growth rate of 2.8 percent during 1981-2002. Real growth in Ethiopia is also much more volatile than in neighboring countries - for example, during this period the standard deviation of growth was 2.2 in Kenya; 2.4 in Tanzania; 3.6 in Uganda; and 4.6 in Zambia.

\footnotetext{
${ }^{8}$ As a share of GDP, claims on the private sector have been broadly stable over the last decade.
} 
Table 4. Ethiopia: Growth in the Region, 1993-2003

\begin{tabular}{|c|c|c|c|c|c|c|c|c|}
\hline & Ethiopia & Kenya & $\begin{array}{l}\text { Ugand } \\
\text { a }\end{array}$ & Tanzania & Rwanda & $\begin{array}{l}\text { Zambi } \\
\text { a }\end{array}$ & $\begin{array}{l}\text { Mozam- } \\
\text { bique }\end{array}$ & $\begin{array}{c}\text { Sub- } \\
\text { Sahara } \\
n \\
\text { Africa } \\
\end{array}$ \\
\hline \multicolumn{9}{|l|}{ During 1983-92 } \\
\hline Average real GDP growth (in percent) & 0.5 & 3.4 & 3.4 & 3.4 & 2.5 & 0.7 & 0.0 & 1.8 \\
\hline Standard deviation of real GFP growth & 8.3 & 2.7 & 4.2 & 2.8 & 5.6 & 3.5 & 8.9 & 1.8 \\
\hline Average GDP per capita growth (in percent) & -2.0 & 0.0 & 1.3 & 0.3 & -0.6 & -2.0 & -1.4 & -1.2 \\
\hline Per capita GDP in 1992 (in U.S. dollars) 2/ 3/ & 142 & 326 & 176 & 165 & 332 & 381 & 138 & 550 \\
\hline \multicolumn{9}{|l|}{ During 1993-2003 } \\
\hline Average real GDP growth (in percent) 4/ & 4.4 & 1.8 & 6.9 & 4.1 & 1.6 & 0.8 & 8.0 & 3.0 \\
\hline Standard deviation of real GDP growth & 4.8 & 1.4 & 2.2 & 1.7 & 20.8 & 5.5 & 3.4 & 1.1 \\
\hline Average GDP per capita growth (in percent) & 1.6 & -0.4 & 3.3 & 1.4 & -0.1 & -2.3 & 5.8 & 0.4 \\
\hline Per Capita GDP in 2001 (in U.S. dollars) 2/ 3/ & 95 & 362 & 242 & 263 & 206 & 343 & 189 & 460 \\
\hline \multicolumn{9}{|l|}{ During 1983-2003 } \\
\hline Average real GDP growth (in percent) 4/ & 2.5 & 2.6 & 5.2 & 3.8 & 2.0 & 0.8 & 4.1 & 2.4 \\
\hline Standard deviation of real GDP growth & 6.8 & 2.2 & 3.6 & 2.2 & 15.2 & 4.5 & 7.5 & 1.6 \\
\hline Average GDP per capita growth (in percent) & -0.1 & -0.2 & 2.4 & 0.9 & -0.4 & -2.2 & 2.3 & -0.3 \\
\hline \multicolumn{9}{|l|}{ Memorandum items } \\
\hline $\begin{array}{l}\text { Private investment in } 2003 \text { (in percent of GDP) } \\
\text { Credit to the private sector in } 2003 \text { (in percent of }\end{array}$ & 10.7 & 11.0 & 17.6 & 13.8 & 12.0 & 11.7 & 30.4 & 12.1 \\
\hline GDP 5/ & 18.4 & 25.6 & 7.3 & 6.6 & 10.4 & 7.7 & 17.0 & $\ldots$ \\
\hline
\end{tabular}

Sources: World Economic Outlook database, IMF, World Development Indicators, World Bank and the country authorities.

1/ Corresponds to 1982/83-2002/03 for Ethiopia. The period 1993-2003 corresponds to the Fund-supported program period under the SAF, the ESAF, and the PRGF arrangement for ex post assessment.

2/ Per capita GNI for sub-Saharan Africa.

3/ Birr was devalued by 59 percent against U.S. dollar in October 1992. Per capita GDP in 1993 was US\$99.

4/ Including 2003/04, real GDP is estimated to have increased on average by 5 percent during 1993-2004 and by 2.9 percent during $1983-2004$.

$5 /$ Credit to the nongovernment sector.

\section{While foreign borrowing has generally been in line with program projections, external debt ratios have increased more than projected} (Figure 6), especially compared with the original program targets, due to unanticipated declines in GDP. ${ }^{9}$ And although the HIPC Initiative will reduce the present value of debt to exports ratio to 150 percent, the ratio is projected to increase over the next few years and remain above 200 percent through 2010. Ethiopia remains one of the most

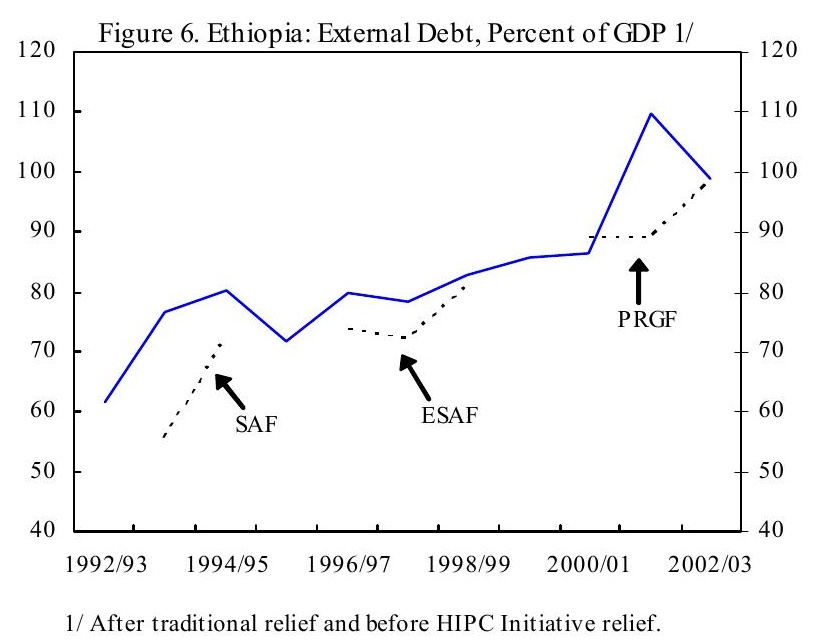

\footnotetext{
${ }^{9}$ The ratio of external debt to GDP amounted to 83 percent at the end of the ESAF, compared with the original projection of 68 percent, while it amounted to 99 percent at the end of the PRGF, compared with an original projection of 90 percent.
} 
vulnerable highly indebted countries, though its debt service burden remains low.

\section{Compliance with program}

targets on government borrowing during the SAF and ESAF arrangements was weak, largely due to the volatility and overprojection of nonproject assistance and tax revenue, but was stronger during the PRGF arrangement. This greater reliance on domestic financing and lower than expected growth, especially during the border conflict with Eritrea, also led to the government's domestic debt remaining at about 40 percent of GDP, systematically higher than projected. The budget remains heavily dependent on concessional foreign financing, and the deficit before grants remains high by international standards and has increased since 1992/93 (Figure 7).

\section{Structural reform objectives}

26. Privatization was slow and targets were frequently missed. Since the beginning of Fund involvement, only about half of the 322 state-owned enterprises have been privatized. Almost all privatization occurred during the SAF and ESAF periods and this initial stage largely comprised privatization of small retail shops, hotels and medium-scale establishments. In 1998/99, the government's intention was to complete the privatization program during 2000/01; this target was subsequently moved to 2003/04, and little progress has been made during the PRGF. Public enterprises still account for about 60 percent of value added in the industrial sector. Other SSA countries, for example, Tanzania, have been significantly more ambitious (Box 2). Also, politically-linked "foundation" companies compete with the private sector in most major sectors of the economy, often with preferential access to contracts, information and finance, and may entail contingent fiscal costs (for example, via NPLs).

27. Private sector development more generally has been weak: the contribution of industry to real GDP has remained at around 12 percent; the share of private investment in the economy remains limited; foreign direct investment remains small; and only about a quarter of investment projects approved have become operational.

\section{Little progress was made towards achieving the government's objectives on} agriculture and food security. With only minor exceptions, the same policy intentions were restated during each of the annual arrangements under the Fund-supported programs. The 


\section{Box 2. Ethiopia and Tanzania-A Comparison}

Both Ethiopia and Tanzania emerged from decades of economic stagnation under a policy of state intervention and planning in the 1990s; Ethiopia in 1992 and Tanzania in 1995. Since then, Tanzania has made greater progress in a number of areas than Ethiopia.

\begin{tabular}{|c|c|c|}
\hline & Ethiopia & Tanzania \\
\hline Banking sector reform & $\begin{array}{l}\text { Financial restructuring of the largest } \\
\text { commercial bank (CBE) started in } \\
\text { November, 2003. The second largest } \\
\text { commercial bank (CBB) to be } \\
\text { privatized soon. }\end{array}$ & $\begin{array}{l}\text { In November 2003, parliament approved } \\
\text { privatization plan for the largest } \\
\text { commercial bank }\end{array}$ \\
\hline Privatization & $\begin{array}{l}\text { Half of all SOEs privatized. Many } \\
\text { strategic corporations remain in state } \\
\text { hands (including the largest } \\
\text { commercial bank, the } \\
\text { telecommunications corporation, } \\
\text { Ethiopian Airlines, and a large number } \\
\text { of industrial enterprises) }\end{array}$ & $\begin{array}{l}\text { Two-thirds of all SOEs privatized } \\
\text { including some strategic corporations } \\
\text { (e.g., the National Bank of Commerce, } \\
\text { Port Container Terminal, } \\
\text { Telecommunications, and Air Tanzania). }\end{array}$ \\
\hline Land reform & $\begin{array}{l}\text { Some reforms have been implemented } \\
\text { to improve security of tenure. Land, } \\
\text { however, cannot be offered as } \\
\text { collateral. }\end{array}$ & $\begin{array}{l}\text { Land Act revised to allow land to be used } \\
\text { as collateral, including the preparation of } \\
\text { a land registry. }\end{array}$ \\
\hline $\begin{array}{l}\text { Private sector credit } \\
\text { growth (av. 2001-03) }\end{array}$ & -2 percent & 35 percent \\
\hline $\begin{array}{l}\text { Foreign direct } \\
\text { investment (av. 2001-03) }\end{array}$ & 0.3 percent of GDP & 3.3 percent of GDP \\
\hline $\begin{array}{l}\text { Current account deficit } \\
\text { excluding grants, (av. } \\
\text { 2001-03) }\end{array}$ & $\begin{array}{l}11.8 \text { percent of GDP } \\
\text { ( } 4.7 \text { percent, including grants) }\end{array}$ & $\begin{array}{l}8.5 \text { percent of GDP } \\
\text { ( } 3.9 \text { percent, including grants) }\end{array}$ \\
\hline $\begin{array}{l}\text { Fiscal deficit excluding } \\
\text { grants, (av. 2001-03) }\end{array}$ & $\begin{array}{l}13.6 \text { percent of GDP } \\
\text { ( } 7.7 \text { percent, including grants) }\end{array}$ & $\begin{array}{l}6.4 \text { percent of GDP } \\
\text { (1.5 percent, including grants) }\end{array}$ \\
\hline $\begin{array}{l}\text { Domestic savings (av. } \\
2001-03 \text { ) }\end{array}$ & 2.5 percent of GDP & 9.0 percent of GDP \\
\hline $\begin{array}{l}\text { Private investment (av. } \\
\text { 2001-03) }\end{array}$ & 9.7 percent of GDP & 13.5 percent of GDP \\
\hline HIPC completion point & April, 2004 & November, 2001 \\
\hline
\end{tabular}


principal objective of the government's agricultural policy since the start of the reform program was to ensure food security through increased production, employment and income, and to increase foreign exchange earnings through increased exports. Yet agricultural productivity remained broadly unchanged during the reform period, production remained extremely vulnerable to recurring droughts, and food insecurity remained a critical problem (with around five million people requiring food aid, even in a "normal" year).

\section{Various factors underlay weak progress in strengthening the agricultural sector,} including: (1) slow implementation of reforms aimed at improving productivity;

(2) environmental degradation; (3) lack of effective and efficient input and output markets which have significantly increased marketing costs, and during times of bumper crops, to price collapses which reduced farm incomes; (4) lack of progress in enhancing security of land tenure; (5) lack of access to appropriate technical advice as extension agents were preoccupied with input supply and credit administration instead of delivering advisory services; (6) insufficiently developed irrigation infrastructure; and (7) lack of access to financial services. Recognizing these impediments to stronger performance of agriculture, the government's PRSP and the recently developed Food Security Program incorporate various initiatives to address them.

\section{Many opportunities to benefit from international trade and finance remain to be} seized. Ethiopia's trade restrictiveness index is above that of similar countries, while its trade, and especially its exports, as a share of GDP are well below other countries in the region and has often been below projections. Ethiopia is yet to accept the obligations under Article VIII of the Fund's Articles of Agreement. ${ }^{10}$ The current tariff system still has a fairly high average tariff and affords many domestic manufacturing sectors high rates of effective protection and raises costs for exporters requiring imported inputs. Exports continue to be dominated by agricultural products, especially coffee. Export support services are poor, bonded warehouse and duty drawback systems are virtually inactive, and a wide array of structural impediments hold back exports (for example, credit, land availability, and infrastructure). Ethiopia has also not yet taken full advantage of membership and participation in trade organizations and special facilities (WTO, AGOA, EBA, and COMESA). Customs procedures remain cumbersome, though significant progress in customs reform has been made since 2003.

\section{Despite chronic weaknesses in staffing and training, civil service reforms lacked} focus and substance, and were characterized by spotty implementation. A review of the size of the public sector and wage policy was advised at the outset of the SAF program in 1992, but was not completed for several years. Strategies on human resource management

\footnotetext{
${ }^{10}$ The remaining Article VIII restrictions relate to: (1) a tax certification requirement for repatriation of investment income; (2) restrictions on repayment of legally entered into external loans and suppliers and foreign partner's credits; (3) rules for issuance of import permits; and (4) a requirement to provide a clearance certificate from NBE to obtain import permits.
} 
and service delivery were subsequently formulated, but not implemented. At the same time, wages and employment grew sharply, reflecting ad hoc salary adjustments and rapid decentralization.

32. While some progress was achieved, some key financial sector objectives have not been met, and Ethiopia's financial system lags that of many other SSA economies. A competitive, market-orientated financial system has not yet emerged: investment in the financial system is still not fully liberalized, as no foreign investments are allowed, and the banking system carries the legacy of the centrally-planned past, as the overwhelming majority of its assets and deposits are held by the CBE (although the CBE's share has decreased over time); another state-owned bank (the CBB), although scheduled for privatization for the last three years, remains in the state's hands. Financial markets are also shallow and dominated by the CBE.

\section{Compliance with Program Conditionality}

33. Compliance with program conditionality has been generally good: less so during the ESAF and more so during the PRGF (Tables 5, 6 and Appendix). With the exception of patchy performance on credit to the government, most quantitative targets were generally met. All structural performance criteria were met, though there was a marked difference in the number and composition of structural performance criteria between the ESAF and PRGF. ${ }^{11}$ The utilization of structural conditionality during the ESAF was affected by poor performance under the arrangement. Prior actions were used extensively during the PRGF to achieve important objectives in fiscal and financial policies - all of the prior actions were implemented. The SAF used structural benchmarks heavily and compliance was poor, with less than half being met. Most of the structural benchmarks under the ESAF were met.

34. All reviews under the SAF and so far under the PRGF have been completed. The fourth PRGF review was held up for six months due to delay in completing the financial audit of the CBE (structural benchmark).

\section{The ESAF was more problematic and strained relations with the authorities.}

Only two of the six disbursements were made. The mid-term reviews under both the first and second annual arrangements were not completed and the program then expired.

- $\quad$ The mid-term review of the first annual ESAF arrangement was not concluded largely due to a failure to reach understandings on the structural reform agenda (including external current account liberalization and CBE reform) and the start of the conflict with Eritrea.

\footnotetext{
${ }^{11}$ Structural performance criteria did not exist under SAFs.
} 
Table 5. Ethiopia: Compliance with Quantitative Program Targets Under the SAF, the ESAF, and the PRGF Arrangements, 1992/93-2003/04 1/

1992/93 1993/94 1995/96 Dec. 96 Dec. 98 Mar. 01 Sep.01 Mar. 02 Sep.02 Sep. 03

A. Quantitative performance criteria 2/

Net domestic assets of the banking system

$\begin{array}{cccccccccc}\text { M 2/ } & \text { M 2/ } & \text { M 2/ } & \text { NM 3/ } & \text { M 3/ } & \text { NR } & \text { NR } & \text { NR } & \text { NR } & \text { NR } \\ \text { NM 2/ } & \text { NM 2/ } & \text { M 2/ } & \text { NM 3/ } & \text { M 3/ } & \text { NR } & \text { NR } & \text { NR } & \text { NR } & \text { NR } \\ \text { M 2/ } & \text { M 2/ } & \text { NM 2/ } & \text { NM 3/ } & \text { NM 3/ } & \text { NR } & \text { NR } & \text { NR } & \text { NR } & \text { NR } \\ \text { NR } & \text { NR } & \text { NR } & \text { NR } & \text { NR } & \text { M } & \text { M } & \text { M } & \text { M } & \text { M } \\ \text { NR } & \text { NR } & \text { NR } & \text { NR } & \text { NR } & \text { M } & \text { W } & \text { M } & \text { M } & \text { M } \\ & & & & & & & & & \\ \text { NR } & \text { NR } & \text { NR } & \text { NR } & \text { NR } & \text { M } & \text { M } & \text { M } & \text { M } & \text { M }\end{array}$

eiling on net domestic financing of the genera

government (incl. privatization receipts)

B. Continuous quantitative performance criteria

Ceiling on outstanding external payments arrears of the public sector

Ceiling on new nonconcessional external debt contracted or guaranteed by the public sector $6 /$

M 2/

M 2/

M 3/

M 3/

M

M

M

M

Source: Staff assessment.

1/ $\mathrm{M}=$ met, $\mathrm{NM}=$ not met, $\mathrm{W}=$ not met and waiver was granted, and $\mathrm{NR}=$ not relevant, that is, the particular item was not a performance criteria during that test date.

2/ All the quantitative targets were benchmarks under the SAF arrangement. Quarterly benchmarks were set under each annual program corresponding to the fiscal year, but only the overall assessment was made for the whole fiscal year. The SAF arrangement did not require the assessment of the performance under the third annual program (1994/95).

3/ Based on information provided in the context of the 1997 and 1999 Article IV consultations. Mid-term reviews under the ESAF arrangement did not take place. For the first annual program (1996/97), understandings could not be reached on a policy framework, especially on structural reforms, and the annual program expired in October 1997 without concluding the mid-term review. The second annual program (1997/98) was approved in September 1998, but the mid-term review was not completed as progress with implementing a broard-ranging agenda of structural reforms was uneven. The three-year ESAF arrangement expired in October 1999 without a third annual program.

4/ The PRGF fourth review was postponed by six months due to a delay in completing a financial audit of the CBE, and no performance criteria were set for end-March 2003.

5/ Under the ESAF arrangement, minimum net international reserves of the banking system.

6/ Short-term import credits and long-term financing operations of Ethiopian Airlines were excluded under all the Fund-supported programs. 
Table 6. Ethiopia: Program Conditions Versus Other Similar Arrangements

Number of Structural Conditions

\begin{tabular}{|c|c|c|c|c|}
\hline \multirow{2}{*}{$\begin{array}{l}\text { Structural } \\
\text { Benchmarks } \\
(3-\text { yr total })\end{array}$} & \multirow{2}{*}{$\begin{array}{l}\text { Performance } \\
\text { Criteria } \\
\text { (3-yr total) }\end{array}$} & \multirow{2}{*}{$\begin{array}{c}\text { Prior } \\
\text { Actions 1/ } \\
\text { (3-yr total) }\end{array}$} & \multicolumn{2}{|c|}{$\begin{array}{c}\text { Total } \\
\text { Structural Conditions }\end{array}$} \\
\hline & & & 3-yr total & Avg per yr \\
\hline 17 & 0 & 0 & 17 & 5.7 \\
\hline$\cdots$ & $\cdots$ & $\cdots$ & $\cdots$ & $\cdots$ \\
\hline 8 & 4 & 0 & 12 & 4.0 \\
\hline 24 & 9 & 12 & 45 & 15.0 \\
\hline 9 & 7 & 19 & 35 & 11.7 \\
\hline 18 & 9 & 3 & 36 & 12.0 \\
\hline
\end{tabular}

Source: Fund documents.

1/ Including prior actions at start of program.

- $\quad$ The mid-term review of the second annual ESAF arrangement was not concluded largely due to the escalation of the conflict with Eritrea, which precluded understandings being reached on a macroeconomic framework. The program had been premised on differences being resolved peacefully.

\section{These interruptions in Fund} disbursements seem appropriate. In particular, the conflict with Eritrea substantially undermined the likelihood of meeting the objectives of the ESAF (Figure 8). Defense spending increased rapidly to very high levels, domestic debt reversed its previous decline and rose sharply and capital spending was compressed. Conflicting World Bank policies also probably did not help smooth relations with the authorities.
Figure 8. Fiscal Impact of 1998-2000 Conflict with Eritrea (in Percent of GDP)

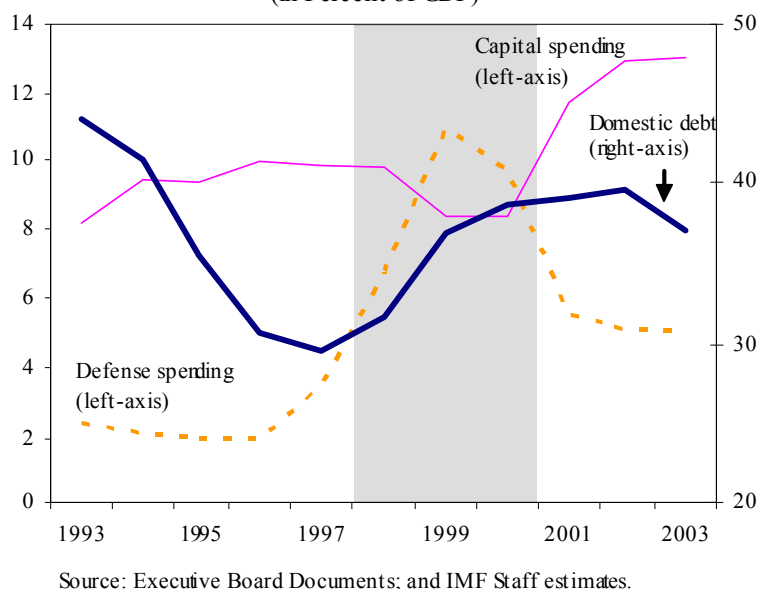




\section{Were the Objectives and the Program Design Appropriate?}

\section{While compliance with conditionality has generally been good, and} macroeconomic stability was secured, it was not enough to achieve the broader development goals. The structural reform agenda was too gradual, resulting in growth that was both well below projections and highly volatile. Program design also did not generally consider, nor was it robust to, the high volatility of growth and the large exogenous shocks to which the economy remained subject.

\section{This gradual and cautious approach to structural reform is evident in almost all} areas. Some areas in particular where more could have been done include: privatization; agricultural reform; land reform; trade reform, especially in the mid-1990s when reserves were comfortable; attraction of foreign investment; civil service reform; and financial sector reform. Some of these areas were, however, largely outside the Fund's area of expertise and not subject to Fund conditionality.

\section{Ethiopia's debt sustainability}

remains precarious even after three successive Fund-supported programs and the HIPC completion point, and fiscal and external $^{12}$ deficits remain large (Figure 9). The spending generated by the high deficits, judging by the lower than projected and volatile growth rates, does not seem to have been sufficiently effective in generating diversified growth, though there have been considerable improvements in some social indicators. Thus, a case can be made that:

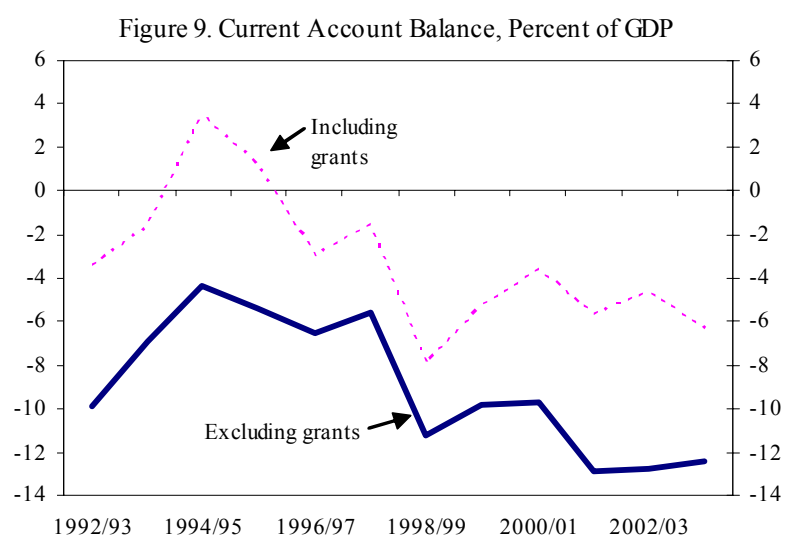

- $\quad$ arrangements, especially the ESAF and PRGF, should either have been less accommodating of such large fiscal and current account deficits, or should have sought more ambitious reforms to support the strong growth projections; and

- $\quad$ more should have been done to attract private FDI. ${ }^{13}$

\footnotetext{
${ }^{12}$ At 12 percent of GDP, the current account deficit (before grants) is double the level of other PRGF countries and is several percentage points higher than the average for either SSA countries or HIPC post-decision point countries.

${ }^{13}$ FDI inflows covered only 8 percent of the current account deficit in Ethiopia during 1990-2001, compared to an average of 22 percent for SSA countries (excluding Nigeria and South Africa).
} 
40. A case could also be made that a more depreciated real exchange rate (and higher NFA floors) might have been appropriate. However, management of the exchange rate on balance appears to have been appropriate. On one hand, there are the large and rising current account deficits and import bills, sluggish growth, and low levels of exports. While the growing deficits were financed by large amounts of resources, debt sustainability was weakened. On the other hand, services and non-coffee exports have been

Figure 10. Ethiopia: Exports of Non-Coffee and Services, Percent of GDP

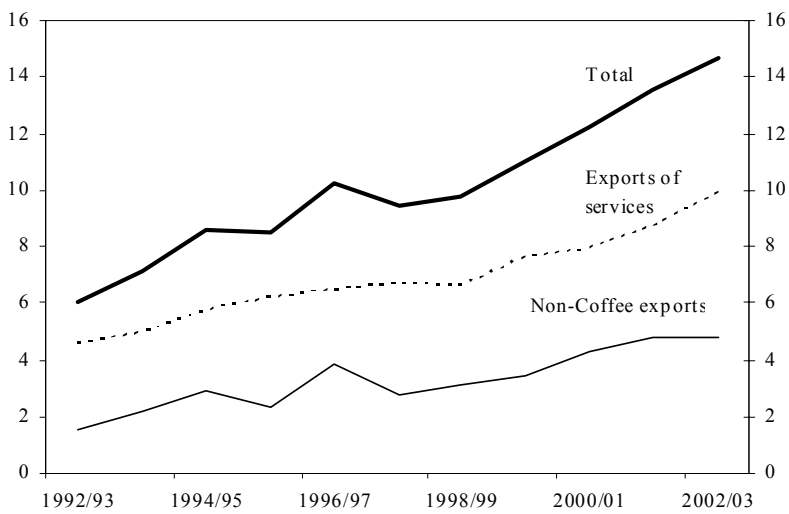
growing strongly (Figure 10), and export problems may be largely structural.

41. Performance criteria on government bank borrowing during the SAF and ESAF arrangements did not allow for higher borrowing if foreign financing fell short of the projected level, though this deficiency was rectified under the PRGF. With foreign assistance to the budget being both highly volatile and systematically overprojected, this led to breaches of the targets, and undermined the macro framework.

42. The design of quantitative performance criteria on government borrowing from the domestic banking system was deficient. Under the PRGF-supported arrangement, as under previous arrangements, the performance criterion for government borrowing from the banking system was set on a flow basis starting from the beginning of the fiscal year (July). However, as test dates were often set for end-September and end-March, this allowed slippages in the last quarter without triggering a breach of the performance criterion.

43. Tax revenues tended to be over-projected. Only in two of the program years were the projections, as a ratio to GDP, met. During the SAF and ESAF arrangements, the shortfalls seem mainly due to envisaged measures not taken and downward revisions to previous year tax bases after the initial projections were made (estimates of tax revenue ratios for any given year vary substantially over time). During the PRGF arrangement, tax revenue increases seem less based on explicit tax policy measures and the explanations of shortfalls due to drought do not seem sufficient as shortfalls also occurred in nondrought years and agriculture is not a major tax handle. This overprojection of tax revenue was flagged in the internal review process but did not lead to a significant change in the projections.

44. Financial sector reform, particularly of the CBE, should have more directly addressed core problems and should have been introduced earlier. Staff realized early on that the overhaul of the financial system required the emergence of private banks, but during the early 1990s, staff papers do not mention the need to reform the CBE. Even once CBE reform was on the agenda, the authorities remained reluctant to proceed expeditiously and comprehensively with banking reform, and remained opposed to any foreign entry. Detailed performance criteria were placed on financial sector reform, but the required actions were not sufficient to address core problems. Looking ahead, it will be important to implement the 
recently adopted restructuring plan for the $\mathrm{CBE}$, and monitor progress with conditionality on critical elements of the plan.

\section{E. Co-operation with the World Bank}

45. Fund-Bank collaboration was initially poor, as reflected by criticism of the Fund's role in Ethiopia by the Chief Economist of the Bank in the late 1990s, and the disagreement regarding the restructuring of the CBE. Collaboration has, however, improved markedly since the PRGF. Bank advice in the mid-1990s often contradicted that of the Fund in key areas and relatively little of Bank-supported programs was picked up in Fund documents. Fund involvement in the area of expenditure policy has been more constrained than in tax policy and administration, reflecting the lead role of the World Bank. Fund technical assistance has focused on intergovernmental fiscal relations, with major reports produced in 1996 and 2002. The World Bank's work on public expenditure reviews and public investment planning has been described in Fund program documents, but there has been little conditionality or other focus on the quality or impact of spending. This has improved under the PRGF and HIPC initiative, although there continues to be little sense of linkage of investment spending to improvements in infrastructure, agriculture, food security, or government administration.

46. Collaboration has been important in the context of PRGF program discussions on the financial sector (especially $\mathrm{CBE}$ restructuring plan), and debt sustainability. The decision point under the HIPC Initiative was reached in 2001, and the completion point was reached in 2004. The Bank has led the policy dialogue on structural reforms relating to privatization, private sector development, rural development, health, education, infrastructure, water, capacity building, governance, and vulnerability. It is also providing assistance for civil service reform, legal and judicial reforms and urban management. The Bank and Fund have shared responsibility in providing technical assistance supporting the decentralization process.

\section{F. Aid Effectiveness and Outlook}

47. Since the 1960s, donors have aimed to promote growth, alleviate poverty, and reduce the vulnerability of the economy to shocks. Much of the assistance has been in the form of food aid. Other donor motives, especially geo-strategic goals, have also generated substantial military assistance. Aid had a minimal impact on growth during the Derg regime due to the civil war and poor economic policy environment. But many of the successful structural reforms that have taken place since 1992 under successive Bank- and Fundsupported programs would likely not have been seriously considered, much less implemented, without the support of substantial policy loans and grants from international donors, and associated technical assistance.

48. Aid flows have been modest relative to other countries, but they are expected to increase. The post 1992 reforms initially attracted more external assistance, although Ethiopia still only received aid equivalent to about US\$13 per capita on average during 1993-97, low by the standards of other reforming SSA countries, reflecting its noncolonial 
history and relatively large population. During the conflict with Eritrea (1998-2000) aid fell to about US\$10 per capita, but under the PRGF it picked up. The Bank is the largest donor, and under the current Country Assistance Strategy, IDA envisages assistance increasing to about US $\$ 0.5$ billion per year. Absorbing projected higher aid flows and ensuring its effectiveness in stimulating growth and poverty reduction, however, will require the strong implementation of structural reforms especially in public expenditure management, agricultural reform, and policies to help develop the private sector. Capacity will also likely constrain effectiveness.

\section{Aid flows have not been well captured by fiscal data, and there remains a need} for better reporting of activities by the donors. Donor-financed project disbursements and food aid have been difficult to quantify because of insufficient coordination between the government and donors, especially at the regional level. The failure to capture all donorfinanced spending leads to inefficiencies in the composition of government spending. The (welcome) shifting and coordination of donor assistance towards more direct budget support is likely to alleviate these problems, but it will be important to agree with all donors on a standardized approach to expenditure reporting and to strengthen oversight by the MOFED.

\section{G. Policy Implementation Lessons}

\section{Factors contributing to achieving objectives}

50. Strong ownership was the main reason why policies were implemented and compliance with conditionality was generally strong. This was particularly the case in the PRGF, where the program was more closely aligned with the authorities' policy preferences. Given the effective political control of the policy apparatus, relatively strong rule of law and low corruption (Figure 11), this ownership was directly translated into action.

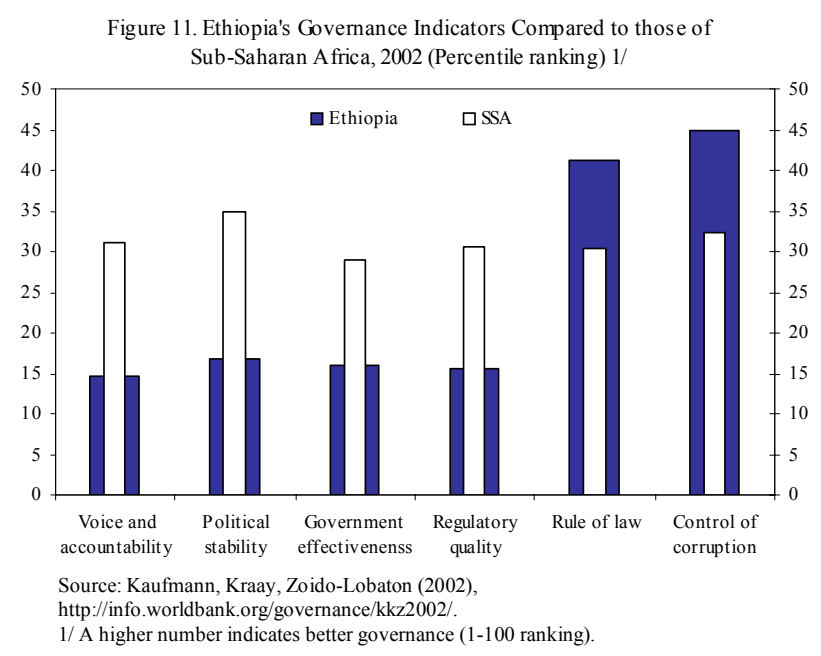

51. The generally satisfactory record of meeting NIR/NFA floors reflected several supporting factors: large inflows of donor assistance, including debt relief from bilateral creditors; surrender requirements on private sector exports; and muted private sector demand for foreign exchange in several years when economic activity and bank lending were depressed. 


\section{Factors impeding achieving program objectives}

52. The authorities have generally been very cautious in more fully pursuing structural reform and embracing the private sector. The structural reforms that have been implemented have typically been gradual and cautious, reflecting the authorities' general risk aversion and concern that reforms should not give rise to excessive social pressure. This is particularly so in the case of the financial sector, where the reform of the CBE begun after a long delay. Political concerns may have also constrained certain reforms, such as land ownership.

53. The 1998-2000 conflict with Eritrea was a huge shock to the economy and stalled the reform process. Casualties of some 50,000 were suffered and an estimated 390,000 Ethiopians were displaced. In addition to the escalating defense costs, lower capital spending and rising domestic debt (see Figure 8), to address growing pressure in the foreign exchange market, the government imposed in January 2000, a 10 percent import duty surcharge, a 100 percent advance deposit requirement for import applications, and nonuniform ceilings across banks on their authority to approve import permits.

\section{Many other general factors impeded achieving program objectives, largely} outside the authorities' control, including the limited physical and human capacity, a complex economic and political transition, and the vulnerability of agriculture to shocks.

\section{Ethiopia scores relatively low on "voice and accountability," political stability,} government effectiveness and regulatory quality. ${ }^{14}$ This speaks to intangible issues not directly within the Fund's mandate, but also reflects the need to strengthen the "rules of the game." For example, property rights could be clarified, as could the role of state-owned and "party-owned" enterprises. And although centralization of political power may well have helped implement policies once decided, the requirement that key decisions be made at the highest level may also have hampered decision making.

\footnotetext{
${ }^{14}$ The Heritage Foundation ranks Ethiopia $101^{\text {st }}$ in terms of "Economic Freedom." This is behind Uganda $\left(48^{\text {th }}\right)$, Côte $d^{\prime}$ Ivoire $\left(89^{\text {th }}\right)$, Kenya $\left(94^{\text {th }}\right)$, Mozambique $\left(95^{\text {th }}\right)$ and Tanzania $\left(98^{\text {th }}\right)$, scoring particularly poorly on government intervention, foreign investment, banking/finance and property rights.
} 
56. Numerous impediments held back the goal of raising exports and foreign investment (Figure 12). For exports, the external environment was generally not favorable, with adverse terms of trade (declining coffee prices) suffered in most of the ten-year period, except the mid-1990s. More generally, there was no export product category that faced rising world demand, suggesting heavy external challenges, even if domestic conditions had been supportive.

But domestic conditions were often not and export supply responses remained limited due to difficulties in areas such as credit, land availability, competition policies, and infrastructure. These factors also deterred foreign investment, as have remaining restrictions in some sectors and perceptions of a difficult business climate.

57. On the fiscal side, specific complicating factors included two rounds of sweeping decentralization. Although caution was expressed on the prospects for adverse financial pressures and the quality of public expenditure, the devolution of fiscal powers to lower levels of government proceeded with little advance planning or preparation, and on an ad hoc basis. The high level of decentralization makes tracking of poverty-reducing expenditure inherently difficult, particularly given weak capacity at district level.

58. Progress with developing a comprehensive reform program for the financial sector was impeded by the preference of the authorities for a more gradual approach, particularly relating to the dominant state-owned CBE, and opening of the financial sector to outside competition. Using experts with experience in transition economies (preferably from Africa), especially early in the period under consideration, might also have been useful.

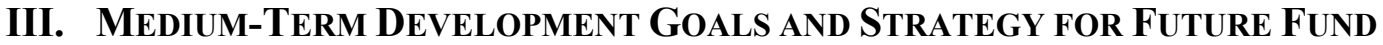 INVOLVEMENT}

59. Ethiopia's medium-term development needs are clear and daunting. Achieving them will take decades. Any strategy for future Fund involvement needs to take this into account.

\section{A. Medium-Term Development Goals}

60. The ultimate objective of the Ethiopian Government is to reduce poverty, mainly by raising real GDP growth sustainably. Consistent with the MDG target, the medium- 
term goal of the government is to halve income poverty from its 1990 level by $2015 .{ }^{15}$ The policy framework within which this objective is to be pursued has recently been formalized in Ethiopia's PRSP, the Sustainable Development and Poverty Reduction Program (SDPRP), which was broadly supported by the staffs of the Fund and World Bank in their Joint Staff Assessment. The SDPRP focuses on promoting agricultural-led, rural-based, growth, while improving the environment for private sector development and export diversification and growth. The SDPRP emphasizes investment in education and infrastructure, capacity building, and improved governance.

\section{The consultations leading to the formulation of the PRSP were unprecedented.} Consultations were held with all levels of society and were attended by independent and donor observers. The draft PRSP was discussed internally within the government and parliament, as well as with civil society, NGOs, and donors. Going forward, the process needs to be continued and deepened.

\section{The principal risk to implementing the SDPRP is the gap between the indicative} program costs and available resources. Estimated costs of the SDPRP over the three-year period 2002/03-2004/05 (including the cost of the three-year Food Security Program) are 138 percent of 2002/03 GDP, while the government's proposed medium-term expenditure framework allocates only 65 percent of 2002/03 GDP to poverty-related spending. The government's ability to fully implement the SDPRP will thus critically depend on the ability to mobilize additional resources. Other risks include the vulnerability to exogenous shocks, tension with the unresolved demarcation of the border with Eritrea, and HIV/AIDS.

\section{B. Strategy for Future Fund Involvement}

\section{Ethiopia's status as one of the most populous poor countries should continue to} compel Fund involvement. Continued involvement would be in line with the Fund's commitment to help achieve the Millennium Development Goals. ${ }^{16}$ More specifically, the Fund can play a critical role in supporting structural reform, financing continued balance of payments needs, coping with exogenous shocks, helping foster and coordinate donor support and consolidating macroeconomic stability:

- $\quad$ while the scope for securing structural reform beyond that which the authorities would otherwise pursue may be small, it is still positive and the reform agenda remains large;

- $\quad$ external vulnerability is still high on a number of dimensions;

\footnotetext{
${ }^{15}$ According to government calculations, based on the 1999/2000 Household Income and Consumption Expenditure Survey, real GDP should increase by 5.7 percent per year until 2015 to achieve the income poverty Millennium Development Goal.

${ }^{16}$ See “The Fund's Support of Low-Income Member Countries_Considerations on Instrument and Financing”
} 
- Ethiopia remains highly vulnerable to exogenous shocks, including drought and coffee prices;

- $\quad$ Fund involvement may help generate donor support, coordination and responsiveness to reform efforts; and

- without substantial continued official support, macroeconomic stability could be threatened.

64. For similar reasons, the Fund should continue to provide technical assistance to strengthen capacity in key areas, such as public expenditure management, revenue administration, tracking poverty-reducing spending, fiscal federalism and financial sector reform. This technical assistance should provide multi-year comprehensive and concrete roadmaps that should be incorporated into program design drawing on experience in similar countries. Other donors should also be engaged.

65. Any future Fund financial support should play a largely catalytic role for highlyconcessional, ideally grant, finance. Although Fund resources are also not likely to be at risk, given the small absolute amounts involved, obligations to the Fund will rise substantially in 2008, and Ethiopia incurred short-term arrears to the Fund on a number of occasions during 1996-2001. ${ }^{17}$

66. Future Fund-supported arrangements should learn from the experience of previous arrangements:

- Given debt concerns, a high-access PRGF should be contemplated only if supporting a major structural reform program, owned by the government and endorsed by and designed in collaboration with the World Bank, that could confidently be seen as laying the basis for a sharp acceleration of growth. Areas covered, mainly through Bank lending conditions, would need to include agricultural sector and land reform, private sector development, and financial sector reforms.

- Absent these conditions, a low-access PRGF or a nonfinancing relationship, involving close collaboration with the government, would be warranted. A lowaccess PRGF arrangement would have the advantage of maintaining a program relationship. Alternatively, the Fund could only be involved in a monitoring/signalling relationship without any financial support, which would still provide a framework for the authorities and donors and maintain a close dialogue.

- More attention should be paid to public debt, especially as Ethiopia is one of the few countries past their completion point where debt sustainability remains a

\footnotetext{
${ }^{17}$ Since December 2003, Ethiopia has authorized the Fund to debit Ethiopia's SDR account automatically when NBE obligations fall due.
} 
threat. Ideally, grant finance will increase substantially to allow pro-poor spending to rise to meet MDGs. But without such grant finance, arrangements should more strictly limit domestic financing of the budget, target lower current account deficits (before grants), and limit concessional external borrowing consistent within a clearly articulated public debt management strategy and regularly updated debt sustainability assessments based on realistic growth projections.

- Growth, grant and tax revenue projections should be more realistic and reflective of the supporting structural policies. In particular, arrangements based on gradualist policies and continued modest grant inflows should not project rapid growth rates. The implications of projected growth rates for individual sectors (especially agriculture) should be more fully fleshed out and their realism assessed. Tax revenue increases should be projected more realistically and based on explicit tax policy (not administrative) measures.

- Arrangements should explicitly incorporate vulnerability to shocks. Ethiopia is almost certain to suffer a major exogenous shock during the three-year period of a Fund-supported arrangement. Broad-brush responses to such shocks should be agreed before the start of the program, and incorporated into program design. For example, contingencies should be explicitly budgeted, greater budget financing should be allowed during "lean" years to be repaid by overperformance during "bumper" years, and alternative scenarios and past experience should be incorporated into macroeconomic frameworks. This should also link with strategies to reduce agricultural vulnerability.

- $\quad$ Real exchange rate appreciation should be avoided. The case that the exchange rate should have been weaker during the program periods is not compelling, but significant real appreciation going forward would seem inappropriate. Avoiding such an appreciation in future arrangements in the event of substantial increases in foreign assistance will be difficult, but could be addressed inter alia through the removal of restrictions on current account transactions.

- Staff should continue and intensify efforts to tailor Fund advice to, and persuade the authorities that Fund-supported reforms will work in, the Ethiopian context. Once the authorities are convinced of a reform, experience shows they will implement it. But they are cautious and need to be persuaded that the reforms will work in the Ethiopian context. This calls for not only continued technical assistance, but also, for example, imaginative outreach programs, such as the seminar on bank restructuring, more use of regional experience and independent advisors, and carefully tailoring recommendations to Ethiopian conditions, leveraging the growing importance of donor assistance, and discussing critical issues outside the program context. Greater understanding of the political economy of blockages to the reform process could also help. 


\begin{tabular}{|c|c|c|c|c|c|c|c|c|c|c|c|c|}
\hline & \multicolumn{3}{|c|}{ SAF Arrangement } & \multicolumn{2}{|c|}{ ESAF Arrangement 1/ } & \multicolumn{7}{|c|}{ PRGF Arrangement } \\
\hline & \multicolumn{3}{|c|}{ Oct. 92-Nov. 94} & \multicolumn{2}{|c|}{ Oct 96- Oct. 99} & \multirow[b]{2}{*}{ Request } & \multirow[b]{2}{*}{ 1st Review } & \multicolumn{2}{|c|}{ Mar. 01-Mar. 04} & \multirow[b]{2}{*}{ 4th Review } & \multirow[b]{2}{*}{ 5th Review } & \multirow[b]{2}{*}{ 6th Review } \\
\hline & $1992 / 93$ & 1993/94 & $1994 / 95$ & $1996 / 97$ & 1998/99 & & & 2nd Review & 3rd Review & & & \\
\hline \multicolumn{13}{|l|}{ Prior Actions } \\
\hline Submit draft tax legislation to parliament & & & & & & $\sqrt{ }$ & & & & & & \\
\hline Sterilize excess reserves of commercial banks & & & & & & $\sqrt{ }$ & & & & & & \\
\hline $\begin{array}{l}\text { Announce publicly that tender for management contract } \\
\text { for Commercial Bank of Ethiopia (CBE) will be offered } \\
\text { in January } 2001\end{array}$ & & & & & & v & & & & & & \\
\hline $\begin{array}{l}\text { Submit satisfactory CBE draft tender document for } \\
\text { review }\end{array}$ & & & & & & $\sqrt{ }$ & & & & & & \\
\hline Announce publicly that a VAT will be introduced in 2003 & & & & & & $\sqrt{ }$ & & & & & & \\
\hline $\begin{array}{l}\text { Eliminate trade restrictions and adiminstrative controls on } \\
\text { access to wholesale foreign exchange auction }\end{array}$ & & & & & & v & & & & & & \\
\hline $\begin{array}{l}\text { Increase top sales tax rate to } 15 \text { percent and eliminate } 10 \\
\text { percent import duty surcharge }\end{array}$ & & & & & & $\sqrt{ }$ & & & & & & \\
\hline \multicolumn{2}{|l|}{$\begin{array}{l}\text { Adoption by Council of Ministers of a budget for } \\
2001 / 02 \text { consistent with fiscal framework presented in }\end{array}$} & & & & & & v & & & & & \\
\hline $\begin{array}{l}\text { Issuance of government guarantees for net claims owed } \\
\text { by the Commercial Bank of Eritrea to the CBE and } \\
\text { commercial bank losses arising from imported goods } \\
\text { stranded in Eritrea }\end{array}$ & & & & & & & $\checkmark$ & & & & & \\
\hline \multicolumn{13}{|l|}{$\begin{array}{l}\text { Reconstitution of CBE Board to put three individuals } \\
\text { from the private sector on the board, and increase the } \\
\text { number of directors from } 7 \text { to } 10\end{array}$} \\
\hline $\begin{array}{l}\text { Appoint new management team to operate } \mathrm{CBE} \text { on } \\
\text { commercial basis }\end{array}$ & & & & & & & & $\sqrt{ }$ & & & & \\
\hline $\begin{array}{l}\text { Revise recently adopted regulation for provisioning by } \\
\text { banks for NPLs to bring it more in line with international } \\
\text { best practice }\end{array}$ & & & & & & & & & $\sqrt{ }$ & & & \\
\hline $\begin{array}{l}\text { Adoption by Council of Ministers of a budget for } \\
2002 / 03 \text { consistent with fiscal framework presented in } \\
\text { LOI }\end{array}$ & & & & & & & & & v & & & \\
\hline $\begin{array}{l}\text { Tendering financial audit of CBE to internationally } \\
\text { reputable audit firm }\end{array}$ & & & & & & & & & $\sqrt{ }$ & & & \\
\hline $\begin{array}{l}\text { Revision of recently adopted regulation for provisioning } \\
\text { by banks for NPLs to bring it more in line with } \\
\text { international best practice }\end{array}$ & & & & & & & & & & $\sqrt{ }$ & & \\
\hline Complete audit of $\mathrm{CBE}$ by reputable international firm & & & & & & & & & & $\sqrt{2} /$ & & \\
\hline $\begin{array}{l}\text { Hire reputable international management consultant to } \\
\text { help CBE operate effectively on commercial basis and } \\
\text { improve its financial performance }\end{array}$ & & & & & & & & & & v & & \\
\hline $\begin{array}{l}\text { Adoption by Council of Ministers of a budget for } \\
2003 / 04 \text { consistent with fiscal framework presented in } \\
\text { LOI }\end{array}$ & & & & & & & & & & $\sqrt{ }$ & & \\
\hline $\begin{array}{l}\text { As part of restructuring of CBE, institute policy to limit } \\
\text { renewal or restructuring of NPLs to two iterations }\end{array}$ & & & & & & & & & & & $\checkmark$ & \\
\hline
\end{tabular}




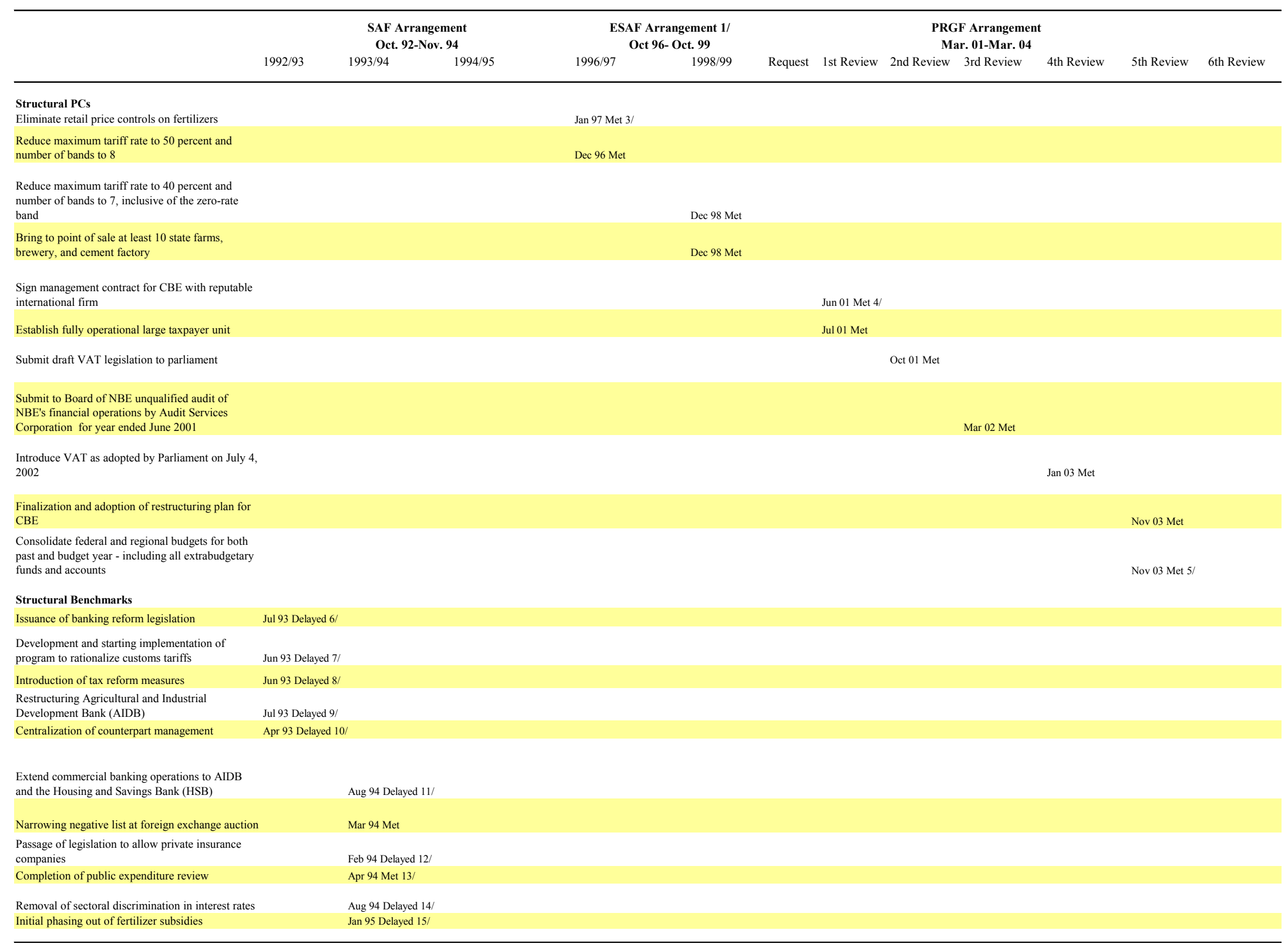




\begin{tabular}{|c|c|c|c|c|c|c|c|c|c|c|c|}
\hline & \multicolumn{2}{|c|}{$\begin{array}{l}\text { SAF Arrangement } \\
\text { Oct. 92-Nov. } 94\end{array}$} & \multicolumn{2}{|c|}{$\begin{array}{l}\text { ESAF Arrangement 1/ } \\
\text { Oct 96- Oct. } 99\end{array}$} & \multirow[b]{2}{*}{ Request } & \multicolumn{4}{|c|}{$\begin{array}{l}\text { PRGF Arrangement } \\
\text { Mar. 01-Mar. 04 }\end{array}$} & \multirow[b]{2}{*}{ 5th Review } & \multirow[b]{2}{*}{ 6th Review } \\
\hline 1992/93 & 1993/94 & $1994 / 95$ & 1996/97 & 1998/99 & & 1st Review & 2nd Review & 3rd Review & 4th Review & & \\
\hline Eliminate negative list at foreign exchange auction & & Mar 95 Partially met & & & & & & & & & \\
\hline $\begin{array}{l}\text { Passage of legislation allowing reform of income } \\
\text { taxation }\end{array}$ & & Dec 94 Met & & & & & & & & & \\
\hline $\begin{array}{l}\text { Passage of legislation allowing reform of capital } \\
\text { gains taxation }\end{array}$ & & Dec 94 Met & & & & & & & & & \\
\hline $\begin{array}{l}\text { Realization of targets for divestiture offers under } \\
\text { privatization program }\end{array}$ & & Jun 95 Partially met $16 /$ & & & & & & & & & \\
\hline Introduction of Treasurey Bill Auctions & & Jan 95 Delayed 17/ & & & & & & & & & \\
\hline $\begin{array}{l}\text { Introduction of minimum deposit and maximum } \\
\text { lending rates }\end{array}$ & & Dec 94 Met & & & & & & & & & \\
\hline $\begin{array}{l}\text { Implement semiannual review for adjusting } \\
\text { petroleum product prices }\end{array}$ & & & Sept 96 Met & & & & & & & & \\
\hline Publish national consumer price index & & & Oct 96 Met 18/ & & & & & & & & \\
\hline Reduce reporting lag of BOP statistics to one quarter & & & Mar 97 Met & & & & & & & & \\
\hline Realize objectives under privatization program & & & Jun 97 Partly Met 19/ & & & & & & & & \\
\hline $\begin{array}{l}\text { Operationalize interbank money and foreign } \\
\text { exchange markets }\end{array}$ & & & & Sept 98 Met & & & & & & & \\
\hline $\begin{array}{l}\text { Reduce reporting lag of monetary statistics to one } \\
\text { month }\end{array}$ & & & & Dec 98 Met & & & & & & & \\
\hline $\begin{array}{l}\text { Issue invitations and select independent and } \\
\text { internationally reputable firm to conduct } \\
\text { comprehensive financial and managerial audit of } \\
\text { CBE }\end{array}$ & & & & Dec 98 Met & & & & & & & \\
\hline $\begin{array}{l}\text { Realize remaining objectives under privatization } \\
\text { program }\end{array}$ & & & & Jun 99 Not met & & & & & & & \\
\hline Establish task force to implement tax reform & & & & & & Apr 01 Met & & & & & \\
\hline $\begin{array}{l}\text { Terminate wholesale foreign exchange auction and } \\
\text { move foreign exchange operations to interbank } \\
\text { market }\end{array}$ & & & & & & & Oct 01 Met 20/ & & & & \\
\hline $\begin{array}{l}\text { Adopt regulation for provisioning by banks for } \\
\text { NPLs in line with international best practice }\end{array}$ & & & & & & & & Mar 02 Met $21 /$ & & & \\
\hline $\begin{array}{l}\text { Sign performance contract with CBE to ensure it is } \\
\text { operated effectively on commercial basis }\end{array}$ & & & & & & & & June 02 Met & & & \\
\hline
\end{tabular}

\section{OInternational Monetary Fund. Not for Redistribution}




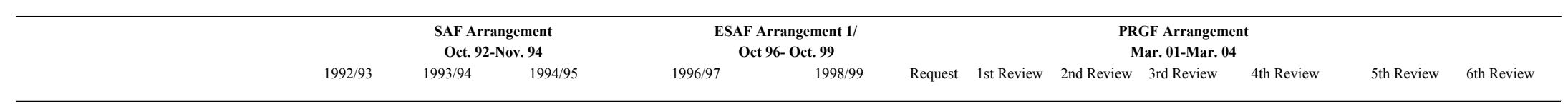

Reduce NPLs by Birr 0.8 billion (from Birr 3.9

billion at end-December), including through write-

offs

Sept 02 Not met 22

Reconcile monetary and fiscal accounts

Dec 03 In progress 23/

Finalization of restructuring plan for NBE based on

Dec 03 Ongoing

recent KPMG study

Jan 04 Ongoing

Full provisioning by all commercial banks for
NPLs in line with existing NBE directive

As part of CBE restructuring, transfer cofinanced

loans from CBE to DBE in exchange for

government guaranteed bond, and eliminate the

maximum annual write-off limit

1/ The first annual program expired in October 1997 as the midterm review could not be completed. The second annual program was approved in October 1998, and the three-year ESAF arrangement expired in October 1999 without a third annual program.

2/ Originally was set as structural benchmark for end-January 2003.

3/ This PC was met in early January 1997, compared with a test date of end-December 1996.

4/ Management contract was signed on June 29, 2001. However, the foreign bank withdrew from the contract in early January 2002

$5 /$ Initially was set as structural benchmark for completion by September 2002, but achievement was delayed because of ongoing decentralization process.

6/ Set as benchmark for end-May 1993.

7/ Set as benchmark for end-March 1993.

8/ Set as benchmark for end-December 1992.

10/ Set as benchmark for end-December 1992.

1/ Set as benchmark for end-December 1993. Achieved only for HSB

12/ Set as benchmark for end-December 1993.

13/ Initially set as structural benchmark for end-May 1993.

14/ Set as benchmark for end-June 1994

15/ Set as benchmark for end-May 1994

16/ Initially set as structural benchmark for end-June 1994.

17/ Set as benchmark for end-December 1994.

18/ Benchmark was set for end-September 1996.

19/ The benchmark relating to the offering for sale, return to previous owners of confiscated entities, or closure of the remaining 72 enterprises from the first stage of privatization was met. However the envisaged offering of at least 26 additional

enterprises and 27 state farms was not observed as only 16 enterprises, and no state farms, were put up for sale.

20/ Test date was October 1, but benchmark was met on October 29 because of delayed provision of technical assistance following suspension of travel related to the events of September 11, 2001.

21/ A first directive was adopted on March 30, 2002, but was revised on August 31, 2002 to bring it more fully in line with international best practice.

22/ Although NPLs were reduced by Birr 0.75 billion more than the benchmark, NPLs at end-September were Birr 0.55 billion higher than benchmark.

23/ Initial date as September 2002, then revised to December 31, 2002. Progress was delayed because of ongoing fiscal decentralization process. 